\title{
Acquisition of passive immunity in domestic ungulates
}

\author{
J.-F. Grongnet' ${ }^{1}$ and Christine Duvaux-Ponter ${ }^{2}$ \\ 'Ecole Nationale Supérieure Agronomique and INRA-Laboratoire du Jeune Ruminant \\ 65 Rue de Saint-Brieuc, 35042-Rennes Cedex, France \\ 2Institul National Agronomique de Paris-Grignon \\ 16 Rue Claude Bernard. 75231 Paris Cedex 5. France
}

\begin{abstract}
The ungulates possess an epteriochondrial placenta, which separates the maternal and foetal blood systems and thus reduces the permeability of the placenta to small molecules. Thus, in these species, the colostral imminoglobulins are the main source of protection factors which aid survivat in the first days of life. This review deals with several aspects of passive immunity in ungulate neonates: the type and the origin of colostral immunoglobulins and factors which influence their production in the mother and their absorption form the gastrointestinal tract of the neonate.

Recommendations for farmes to enhance natural postnatal immunity and recent technological advances in the production of immunoglobulin preparations are discussed.
\end{abstract}

KEY WORDS: passive immunity, ungulates

\section{INTRODUCTION}

The majority of domestic mammals are classified in the group of ungulates. They possess an epitheliochorial placenta comprising of six cell laycrs which separate maternal and foetal blood systems. The permeability of the placenta to small molecules is low. Normally, maternal antibodies do not cross the placental barrier and even though its immune system is potentially active the new-born animal is totally unprotected. In the absence of antigenic stimulation, in utero, no antibodies have been produced. After the first aggression a primary type response will occur. 
This response will not be efficient before several days and therefore the situation of the subject will be critical without the ingestion of maternal colostrum. The composition of colostrum will be reviewed here only in relation to immunity with special emphasis on immunoglobulins since the new-born is highly reliant on them for survival.

BLOOD IMMUNOGLOBULIN LEVELS, MORTALITY AND MORBIDITY IN YOUNG ANIMALS

It has been established more than 70 years ago (Smith and Little, 1922) that, in the calf, a strong relationship exists between early ingestion of colostrum and the chances of survival. This relationship has been confirmed many times, notably in France by Dardillat et al. (1978): low concentrations of gammaglobulins in the blood of the new-born or the colostrum of the dam were always followed by elevated mortality and morbidity. Work in this area has been extensive in several species.

Even though a relationship between lower mortality and adequate transfer of passive immunity can be unanimously accepted, what needs to be clarified are the conditions which are a prerequisite for the transfer to be correct. They can be separated into three independent sectors: the quality of the colostrum, the physiological state of the new-born, and the rearing conditions.

\section{COMPOSITION AND QUALITY OF COLOSTRUM}

\section{Type of colostral antibodies}

The antibodies are globulins synthesised in an organism in response to an antigenic stimulus. For this reason these globulins, called immunoglobulins, make up several groups and sub-groups according to their composition, structure and physicochemical properties. There are important differences between species in the partition within the different classes of Ig in the colostrum. In ungulates, the $\operatorname{lgG}$ are predominantly $\operatorname{lgG} 1$. In the cow, $85 \%$ of total colostrum $\lg$ are $\operatorname{IgG}$ with $95 \%$ IgG1 and only 5\% IgG2 (review by Berthon and Salmon, 1993) whereas, in the blood the IgG are much more balanced, 55 and $45 \%$, respectively (Brandon and Lascelles, 1971; Beer et al., 1974). In pig colostrum as opposed to cow's, IgG are only twice as abundant as IgA (Jensen and Pedersen, 1979). In pigs, the IgG have been separated into four sub-groups : IgGA, IgGB, IgGC and IgGD by Rapacz and Hasler-Rapacz (1982). Based on this classification, Huang et al. (1992) have shown, in colostrum, that IgGB were ten times more abundant than IgGA and IgGC. In lagomorphes and primates, $\mathrm{IgA}$ are more abundant. In man, colostrum contains 
about $18 \mathrm{~g} / \mathrm{lgA}$ and only $0.17 \mathrm{~g} / \mathrm{IgG}$ according to Charles and Larsen (1984), while Mehta et al. (1989) recorded for the latter a much higher concentration of $2.5 \mathrm{~g} / \mathrm{l}$. They also showed that IgGl represented $85 \%$ of the total IgG. Lastly, IgM are present in very small quantities in all the species studied : cow (Burton et al., 1989), mare (Kohn et al., 1989) and in man (Charles and Larsen, 1984).

\section{Origin of colostral antibodies}

Colostral IgG come from the plasma of the dam. Ig are transferred into the colostrum by a highly specific transport system (Dixon et al., 1961) which involves the lymphocytes which are present in mammary tissue (Salmon and Delouis, 1982). This transport system explains the very different ratio between IgG1/ IgG2 in colostrum and plasma. Fixation sites with a very high affinity (Sasaki et al., 1977) for IgG have been clearly identified on the basal membranes of glandular epithelium cells (Brandon and Lascelles, 1971; Hammer and Mossman, 1978). These cells proliferate during the period of mammary growth preceding parturition and their growth is affected by oestradiol 17-beta (Delouis, 1978). This hormone could also be involved in the transfer of Ig into the colostrum. This process is characterised by its progressive nature. It is maximal 3 days before parturition (Guidry et al., 1980) and in the cow at the end of the colostral phase a total of about $1.5 \mathrm{~kg}$ of IgG have been transferred from the plasma (Larson et al., 1980), which represents a considerable quantity.

IgM and IgA have a dual origin (Newby and Bourne, 1977). In the sow, only $40 \%$ of IgA come from the blood and the rest is synthesised in situ (Bourne and Curtis, 1973). The same authors underline the fact that once the colostral phase has finished, $90 \%$ of $\operatorname{lgA}$ and $\operatorname{lgM}$ in milk and $70 \%$ of IgG are produced locally, but one should not forget that production is much lower at this time. In man, IgA make up the majority of the antibodies found in colostrum, and as it has been described above they come mainly from the mammary gland (review by Levieux, 1984).

\section{FACTORS WHICH INFLUENCE THE PRODUCTION OF COLOSTRUM AND THE ABUNDANCE OF IMMUNOGLOBULINS}

In relation to protection of the new-born, the quantity of colostrum available is as important as its level of immunoglobulins. The amount of colostrum available probably represents an important limiting factor for passive immunity in the piglet, because of the very high level of prolificity of modern genotypes. This is also probably true for lambs which come from multiple litters and for calves which come from beef heifers. The species, breed and other factors (time after parturi- 
tion, litter size, lactation number, prematurity, feeding and health status) influence the total concentration of immunoglobulins.

The other components of colostrum

Cells

The mammary gland is an organ which is particularly exposed to aggression, bccause of the very large interface with the exterior. Fortunately, the density of lymphoid cells in mammary tissue is very high (Salmon and Delouis, 1982) and they are found at high concentrations in mammary secretions, mixed with the epithelial cells. Milk and colostrum contain about the same number of cells : $10^{6}$ to $10^{7}$ cells $/ \mathrm{ml}$ in the milk and colostrum of the sow (Evans et al., 1982; Schollenberger et al., 1986; Le Jan, 1992) and $3 \times 10^{6}$ cells/ml in human milk. In bovine and ovine colostrum, the number of cells is slightly higher than in milk (Merilainen et al., 1979). Lymphocytes represent a very small proportion of the total population (Lee and Outteridge, 1981) and plasmocytes are absent (Newbold, 1970).

All the authors who have considered the subject of cells in mammary secretions regard them as necessary for cellular immunity provided for the young human or animal. This is even the main argument used by paediatricians when they recommend that maternal milk should be given to babies because even if milk powders are made to be like human milk they do not contain live cells. Bertotto et al. (1990) concluded that the presence of T lymphocytes in human colostrum was not only the result of contamination from blood. They follow a selective homing mechanism which is shown by a high proportion of $\mathrm{T}$ lymphocytes which carry the gamma/delta cellular receptor, compared to that encountered in blood sample $T$ lymphocytes (Bertotto et al., 1991). If the milk cells can provide local protection within the intestine, the cells found in colostrum are not limited to this function since they are absorbed (Tuboly et al., 1988; Williams, 1993). This trans-intestinal passage of colostrum cells obeys specific rules since cells from the same category but from peripheral blood or from heated colostrum migrate at a very low rate across the intestinal wall compared to normal colostrum (Tuboly et al., 1988, Williams, 1993). The contribution of cells to cellular immunity is undeniable and, for example, in the infant a positive response to a tuberculosis test can be seen to be transmitted by suckling (Schlesinger and Covelli, 1977).

Anti-trypsin factor

In order to play a protective role, the lg must enter the animal's internal environment and maintain their structural integrity. In the digestive tract, they face the 
digestive enzymes which have already a high proteolytic activity at birth in the calf (Le Huérou-Luron et al., 1992). Brock et al. (1978) and then Petschow and Talbott (1994) have established that the action of the enzymes effectively reduced the activity of the colostrum Ig and anti-bacterial substances and the immunoneutralising titre of bovine anti-rotavirus $\mathrm{lg}$. Anti-trypsin factor present in colostrum helps to maintain Ig biological activity (Pineiro et al., 1975). In the cow, when the colostrum has a high concentration of Ig it is also rich in anti-trypsin factor (Quigley et al., 1995b). Milk does not contain any anti-trypsin activity except in the case of mastitis (Honkanen-Buzalski and Sandholm, 1981). The positive influence of the presence of anti-trypsin factor on the concentrations of circulating colostral Ig appears undeniable (Jensen and Pedersen, 1979; Carlsson et al., 1980). Some authors wanted to go further by increasing the natural activity of anti-trypsin factor in colostrum by the addition of an anti-trypsin factor extracted from soyabean. In the calf their work was a success because they were able to increase the intestinal transfer of lgG (Quigley et al., 1995c).

BLOOD IMMUNOGLOBULIN LEVELS AND THEIR ABSORPTION IN THE NEW-BORN

\section{Physiological mechanism and site of absorption}

The enterocytes play an important role in the transport of Ig. Throughout the life time of an organism the enterocytes transport Ig from the general circulation to the intestinal lumen in order to protect the mucosal tissue which is exposed to numerous microbial and dietary antigens (Brandtzaeg and Krajci, 1995). Around the time of birth the process is in the opposite direction : in order to protect not only locally but mainly systemically the Ig must be transported from the lumen into the blood system without changing structure. This mechanism is an atypical function of the intestine, which normally exerts a barrier effect in relation to large molecules. The mechanisms depend on the animal concerned. In man, it appears to be significant only during foetal life (Israel et al., 1993). In rodents, as presumably in man, the internalisation of Ig into enterocytes is made possible by a specific transport system (Simister and Mostov, 1989), which is present in the micro-villi. The Fc region of the Ig binds with the transporter at the slightly acid $\mathrm{pH}$ which is seen in the lumen of the intestine and dissociates at a $\mathrm{pH}$ of 7.4 which is seen near the basal membrane. This system is not observed in the proximal part of the intestine (Jochims et al., 1994). It disappears at weaning, which therefore marks the end of the trans-intestinal transfer of Ig, a phase often called "closure". It should be noted that this mechanism which implies specificity does not exclude the non-specific 
absorption of other macromolecules (Walker et al., 1972). This type of absorption as opposed to specific absorption occurs in the distal part of the intestine (Jochims et al., 1994).

In ungulates no transporters have been identified so far, and there is no molecular specificity. The Ig and other macromolecules, for example, alpha-lactalbumin (Prosser et al., 1992) can be internalised by pinocytosis. Frenyo (1987) has shown that in the piglet bovine Ig were absorbed as well as porcine Ig. However, this finding was not confirmed by Pierce and Smith (1967) and Drew and Owen (1988), who showed that porcine Ig were absorbed more efficiently than bovine Ig, indicating a relative specificity for macromolecule absorption. The localisation of the phenomena in the small intestine remains controversial.

Penetration into the enterocyte represents only a part of the process. In order to be effective the Ig must enter the systemic system. They enter the lymph (Balfour and Comline, 1962; Payne and Marsch, 1962 a,b; Bush and Staley, 1980) or the lymph and the blood (Kiriyama, 1992). Internalisation and the following liberation of Ig are two independent processes (Fetcher et al., 1983) which can result in the transitory accumulation of Ig in the wall of the intestine, at least in the lamb (Patureau-Mirand et al., 1990). However, only 2 to $3 \mathrm{~h}$ after the ingestion of colostrum by the calf levels of blood Ig sufficient to give protection can be measured (Cabello and Levieux, 1978).

\section{Closure}

In ungulates it occurs much earlier than in rodents. It is progressive : the capacity for the intestine to absorb macro-molecules decreases from birth. This last factor has important implications for husbandry : the farmer must make sure that the animal ingests colostrum as early as possible. The capacity to internalise large molecules is limited to immature enterocytes. Closure is therefore directly linked to epithelium turnover. It is slower in rodents (Klein and McKenzie, 1980) than in ungulates. Turnover starts in the crypts of Lieberkuhn and moves up to the apex of the villi, where some macromolecule absorption is still possible (El-Nageh, 1967 a,b). While in normal conditions, closure is complete 24 to $36 \mathrm{~h}$ after birth (Lecce and Morgan, 1962 ; McCoy et al., 1970), there is a significant reduction before this time in both the young ruminant and the piglet (Bourne and Curtis, 1973 ; Murata and Namioka, 1977; Matte et al., 1982). The rate of epithelium cell turnover is a complex process and is under the control of numerous factors linked directly to the animal or to external factors. Their consequences for the neonatal absorption of $\mathrm{Ig}$ will be very important and will be described below. 


\section{FACTORS INFLUENCING THE ABSORPTION OF IMMUNOGLOBULINS AND THEIR CONCENTRATIONS IN THE BLOOD OF NEW-BORN ANIMALS}

\section{Animal factors}

The influence of hormonal status has been the subject of many studies. Particular attention has been given to adrenal hormones (Malinowska et al., 1972). However, if a pharmacological treatment is not used to alter cortisol levels, it is not usually possible to show a relationship between cortisol around birth and the absorption of Ig in both the lamb (Cabello and Levicux, 1981a, b) and the calf (Cabello and Levieux, 1978; Stott and Reinhard, 1978). James et al. (1981) however, showed in the latter species that low circulating corticosteroid levels were associated with a low level of uptake of $\operatorname{Ig}$ by the intestine.

Bearing in mind the fact that thyroid hormones play an important role in the maturation of the foetus (Cabello and Wrutniak, 1986) they have been often studied. Thyroxin (T4) has a depressive effect on Ig absorption. This has been shown after T4 treatment in rats (Chan et al., 1973), kids (Cabello et al., 1980) and to a lesser extent in calves (Ślebodziński et al., 1995). When using a mixture of triiodothyronine (T3) - T4 administered to lamb foetuses Cabello et al. (1983) also obtained a negative effect on absorption, while Slcbodzinski ct al. (1995) showed in the calf that T3 on its own had a positive effect. Finally, Harada and Syuto (1993) showed in the rat that secretin, which probably acts on the maturation of gastro-intestinal function, accelerated closure.

Abnormal physiological situations also seem to influence the absorption of Ig. For example : Prematurity and induction of parturition: Since the ability to massively internalise macromolecules is specific for the immature intestinal epithelium, the effect of premature birth has been studied. The logical hypothesis was that prematurity had a positive effect on Ig absorption. Indeed, there is a negative correlation between the length of gestation and absorption of $\lg$ (Cabello and Levieux, $1981 \mathrm{a}, \mathrm{b}$ ). While the lighter premature piglets in a litter are not able to ingest the same amount of colostrum they have the same level if Ig, which indicates that absorption is more efficient (Milon et al., 1983). When the new-born is the result of induced parturition the situation is less clear and the prematurity is not necessarily involved (Cabello and Levieux 1981 a,b; Johnston and Stewart, 1986).

Dystocia and hypoxia: Hypoxia resulting from dystocia is a major metabolic handicap which disturbs all vital functions. It has been assumed that the absorption of Ig would be affected by this problem. Tyler and Ramsey (1991) and Dos Santos et al. (1994) using a hypoxia model with colostrum containing exactly the same amount of Ig have shown that hypoxia limited or delayed intestinal absorption of Ig by a mechanism which remains unknown. Part of the explanation could be that the motility of the intestine is reduced but it should not be forgotten that 
disruption at the cellular level may be involved. Tyler and Ramsey (1991) were able to show in the same experiment that the negative effect of hypoxia could be partly overcome by delayed closure. This latter finding remains unexplained cven though hypoxia could perhaps delay the turnover of the intestinal epithelium.

Other factors: Joly (1981) showed that lg absorption was greater in Friesan than in Salers calves, but sex of the neonate had no effect (Halliday, 1978). The weight of the new-born also plays a role. Calves which are lighter at birth have higher blood Ig levels than heavier calves because they are more vigorous at birth and ingest more colostrum. However, Fallon and Harte (1987) were not able to confirm this result. The opposite is true for piglets, hypotrophic piglets consume less colostrum than the others (Milon et al., 1983) because they are not able to gain access to the mammary gland due to competition with littermates.

\section{Environmental factors}

Ambient temperature and the season of birth

Low ambient temperatures do not have a negative effect on the absorption of Ig. Piglets which become severely hypothermic due to exposure to low temperatures, do not exhibit a lower rate of absorption of $\mathrm{Ig}$ when given the same amount of Ig as animals which are not hypothermic (Kelley et al., 1982). The year before the same team obtained the opposite result but this time with natural suckling (Blecha and Kelley, 1981). These previous results are therefore not due to reduced intestinal capacity but to lower levels of ingestion of colostrum under the influence of low temperature as shown by Le Dividich and Noblet (1981). Similarly, in the calf no effect of low temperature on Ig absorption has been found (Cabello and Levieux, 1978; Olson et al., 1980, 1981). It has however been noted that calves which come from cows maintained at a high temperature during the end of gestation have lower plasma Ig levels than calves which come from cows which were during the same period shaded from the sun (Stott, 1980). The effect of season is controversial.

Age of the dam and size of the litter

These factors again probably act through the quantity of colostrum ingested. In ewes, Halliday (1978 and 1979b) showed that the size of the litter was negatively correlated with lamb blood Ig levels. Villette and Levieux (1981) were not able to show the same result when they studied singleton and twin litters.

Older cwes producc lambs which have lower Ig levels (Halliday, 1978; Villette and Levieux, 1981) probably due to a lower suckling activity as a result of poor access to the mammary gland, because the mammary gland is often hypertrophied 
and closer to the ground. The same is true for the calf : the form of the mammary gland affects suckling activity (Derenbach et al., 1983; Ventorp and Michanek, 1992). Age can also affect maternal behaviour of the dam : it is less well developed in the heifers. Their calves suffer from a delay in the first suckling (Derenbach et al., 1983) and their blood Ig levels are lower (Encheva et al., 1987).

\section{Diet composition}

Even if the ingestion of an adequate amount of Ig is always necessary, initial research in the 60 's showed that the success of intestinal transfer of Ig and the occurrence of closure resulted from dietary factors independent of the level of Ig in the diet. Balfour and Comline (1962) showed that Ig added to a saline solution were very poorly absorbed, this has been confirmed by Grongnet et al. (1986). Therefore the key to efficient absorption of Ig appears to be in the colostrum itself. Mehrazar et al. (1993) showed recently that the absorption of macro-molecules was increased by colostrum feeding. Balfour and Comline (1962) extracted a small molecular wcight protein from colostrum which increased the absorption of Ig. However, Grongnet et al. (1996) using a very similar protocol were not able to repeat the finding.

Even though colostrum contains a factor which stimulates absorption it also accelerates closure (Lecce et al., 1964; Tyler and Ramsey, 1993). Indeed, Lecce and Morgan (1962) and Payne and March (1962 a,b) have established that closure was delayed in starved new-born lambs and piglets. This effect of colostrum on closure could be linked to the fact that it contains cellular growth factors (Iivanainen et al., 1992) which have now been identified. It has been clearly shown that the administration of colostrum accelerates intestinal protein synthesis (Burrin et al., 1995), increases jejunal weight (Burrin et al., 1994) and generally stimulates tissue growth (Patureau-Mirand et al., 1990; Reinhart et al., 1992; Kelly et al., 1993). Closure therefore occurs earlier due to faster epithelium turnover.

Numerous experiments have been conducted on substances which could increase macromolecule absorption for example poly-L-arginine, potassium isobutyrate or clinoptilolite, a magnesium clay, but their success have been limited and often contradictory duc to differences in experimental conditions.

Many factors are without or even have a negative effect on absorption : glucose (Klobasa et al., 1994), lactose (Werhan et al., 1981), duodenal juice (James and Polan, 1978), saliva (Balbierz et al., 1976), L-methionine and L-leucine (Smith and Pierce, 1967) and a macro-peptide of casein (Grongnet et al., 1996). Kaeckenbeeck et al. (1967) have shown in the calf that the administration of protein does not alter the subsequent absorption of colostral Ig. The results of Besser and Osborn (1993) are particularly interesting since the addition of bovine serum albumin to serocolostrum greatly limited the absorption of Ig. Therefore, competition 
exists between the different types of macromolecules for transport across the intestinal wall.

Apart from the chemical constituents of the diet other characteristics have been tested. After acidification of colostrum by fermentation the Ig are poorly absorbed (Foley et al., 1978). The coagulation of colostrum in the abomasum has a favourable effect on absorption since absorption is reduced when coagulation is inhibited (Cruywagen, 1990). The bacterial quality of the intestinal content is also important. Inoculation of the digestive tract with intestinal bacteria can limit absorption (James et al., 1981). A similar type of result was observed by Bush et al. (1982), who showed that pasteurisation of colostrum slightly improved absorption, however this was not confirmed by Grongnet et al. (1996). Pasteurisation should be encouraged for other reasons and Li-Chan et al. (1995) showed that careful treatment of Ig results in sufficient thermo-resistance. An alternative to heating is irradiation. Jetteur et al. (1987) showed that the hygienic quality of colostrum can be improved and at the same time the immunoneutralising capacity of the gammaglobulins is maintained after gamma irradiation if the treatment is applied to freezedried or frozen colostrum rather than to liquid colostrum.

\section{The role of the farmer and industry}

The survival of the new-born is highly dependent on adequate plasma levels of Ig. The acquisition of adequate passive immunity depends on: adequate ingestion (first condition), rapidly after birth (second condition) of a colostrum rich in $\mathrm{Ig}$ (third condition). Based on what has already been said concerning the Ig composition of colostrum it is difficult for the farmer to influence the third condition. The farmer can however act to optimise the first and second conditions through an adequate distribution of colostrum: either by natural suckling or by feeding colostrum after milking the dam. It is clear that the recommendations only concern cow-calf and nanny goat-kid where the young is later reared with milk replacers. Lambs, foals and above all piglets are not concerned by these recommendations.

Some authors have found that if the calf is left with the dam the plasma concentrations of $\mathrm{Ig}$ are higher than if the calf is separated from the dam after birth and given colostrum by the farmer (Bielecka, 1987; Karle et al., 1987; Quigley et al., 1995a). However, the comparison of averages is not satisfactory and one needs to look at the dispersion of the results. This large dispersion can first of all be interpreted as the result of differences in the behaviour of both the cow and the calf (Dobbelaar et al., 1987; Encheva et al., 1987). The type of housing can also play a role (Michanek and Ventorp, 1993), either helping or inhibiting access to the mammary gland.

The administration of colostrum by the farmer can solve all the problems described above. When performed carefully, blood levels of Ig are correct (Besser et al., 1991) and there is a smaller percentage of calves with blood Ig levels lower 
than that seen with natural suckling. However, giving colostrum manually is very time consuming compared to leaving the calf with its dam.

The conditions of distribution of colostrum have been extensively studied. Ingestion by bucket or by a feeding bottle are both as effective in providing protection (Dobbelaar et al., 1987; Fallon et al., 1989). In the case of a palatability problem administration by an oesophageal tube is advisable, if performed correctly it is not painful and does not reduce the absorption of $\mathrm{Ig}$ (Al-Jawad and Lees, 1985; Besser et al., 1991). More surprising is the influence of the presence of the dam : for the same level of colostrum ingested, blood levels of Ig are higher when the dam is present than if the dam is not present (Selman et al., 1971a,b; Fallon et al., 1989) suggesting that intestine cell function is affected by the maintenance of the social link dam-offspring. However, these findings could not be confirmed elsewhere (Joly, 1981; Dos Santos et al., 1994a).

Considering the occurrence of intestine closure, the time of the first ingestion of colostrum is particularly important. A single ingestion of colostrum at 2, 4,6 or $8 \mathrm{~h}$ after birth produced the same level of blood Ig (Todd and Whyte, 1995). Michanek and Ventorp (1989) had already shown that the first ingestion of colostrum at $1,8,16$ and even $24 \mathrm{~h}$ after birth gave the same level of protection. However, they did not give one meal of colostrum but several and they observed that the Ig of the subsequent meals were less and less well absorbed when the first ingestion of colostrum was delayed. Globally, the blood levels of Ig were much higher in animals which ingested colostrum for the first time $1 \mathrm{~h}$ after birth. Therefore, it should be recommended that the first ingestion of colostrum should be as early as possible after birth. However, if the farmer has not been able to take care of a new-born calf straight after birth it is still possible to obtain a certain level of protection even if the colostrum is given up to $24 \mathrm{~h}$ after birth.

Once the farmer has followed the recommendations indicated above he cannot be sure that the new-born animals are sufficiently protected by passive immunity. The colostrum that he has distributed is perhaps not rich enough in Ig. If the farmer looses several calves after following the recommendations it can be due to the use of colostrum which is not sufficiently active against the micro-organisms present in the farm. When a cow is affected by mastitis the farmer will hesitate to distribute the colostrum, which is not rich in Ig and unhealthy. If the goat herd or sheep flock is affected by CAEV or Visna-Maedi, respectively, the farmer will not give the maternal colostrum because it is a well-known vector for the retro-viruses concerned. If the farmer has hyper-prolific ewes or sows he may face the problem that the supply of colostrum is too limited for each young. The result of these problems is that the farmer will need to use colostrum which does not come from the dam of the young which need to be treated.

If the farmer has dairy cows the most financially attractive solution is to create, within the farm, a supply of frozen colostrum. By freezing large quantities then 
thawing and mixing different batches of colostrum and then re-freezing small quantities the farmer will have a homogeneous, rich in Ig and easy to use product. The final thawing of the colostrum before giving it to the calf in an emergency can even be performed in a micro-wave oven. This method of thawing does not appear to adversely affect the structure of the immunoglobulins (Jones et al., 1987).

In all the other cases a supply is to be found outside the farm. A market for complements or substitutes for colostrum has recently been developed. The simplest case concerns the supply of Ig for beef calves when their dams are deficient in Ig. For these animals it is necessary to collect colostrum in dairy farms, to dry it industrially and in this way it can be used commercially much more easily than frozen colostrum. The Ig of this type of product can be absorbed efficiently by the intestine (Zaremba et al., 1993). It may be necessary to produce a product which is more concentrated than that which is sometimes delivered by dairy farmers. Therefore, it would be necessary to semi-purify the colostrum, however, this leads to the production of a colostrum for which the Ig are absorbed less efficiently. After this type of treatment, which may eliminate the factor thought to help absorption by Balfour and Comline (1962), the absorption of the Ig can be very low (Grongnet et al., 1986, 1996). This was not the case for Nousiainen et al. (1994) and more recently Grongnet et al. (unpublished results) who showed that absorption and blood Ig levels were sufficient to give protection.

For kids, lambs, foals and piglets the problem is more difficult to solve because colostrum is hard to obtain from the nanny goat, not available from the sow or collection is very difficult from the mare and ewe. It is possible to use successfully bovine colostrum or its derivatives in other ungulates : in the lamb (Al-Jawad and Lees, 1985; Grongnet et al., 1996), in the foal (Lavoie et al., 1989 a,b; Watanabe et al., 1993) and in the piglet (Frenyo, 1987). In the kid it is probably also possible but the results have not been published. Two problems have so far been noted : the Ig are recognised as being foreign and therefore their half-life is shorter (8-9 d) than Ig from the species concerned (21-28 d) in the piglet (Frenyo, 1987) or the foal (Lavoie et al., $1989 \mathrm{a}, \mathrm{b}$ ). The consequence is that there is a breakdown in the protection between the disappearance of the bovine $\mathrm{Ig}$ and the appcarance of the endogenous Ig. The shorter half-life shows that bovine Ig are attacked by the receiver. However, bovine colostrum given to other species can sometimes cause major problems such as anaemia, especially in the lamb, which can be rapid and fatal (Bernadina and Franken, 1983 ; Winter and Clarkson, 1985; Dos Santos and Grongnet, unpublished results). The red blood cells are agglutinated and rapidly destroyed by the reticulo-endothelial system, the haematocrit can be as low as 5 or 6. Death after a haemorrhagic syndrome, without a reduction in haematocrit, has also been described (Schreuder, 1993). Examination of the blood then reveals a severe thrombocytopaenia. Similar problems have been described in the foal because bovine colostrum also caused agglutination of horse red blood cells 
(Lavoie et al., 1989a, b). The problem can be solved by mixing lots of different colostrums before industrial treatment and their administration to new-born animals. Indeed, not all colostrum samples have the same agglutination activity.

The use of Ig from the blood is attractive since blood is readily available in slaughterhouses. The dried serum is a product available in industrial quantities but the Ig quality is not guaranteed. Even without purification, which is however possible, one can expect a certain degree of protection if enough of the product is ingested. Satisfactory results have been obtained in the piglet (Drew and Owen, 1988), in the kid (Constant et al., 1994), in the lamb (Al-Jawad and Lees, 1985) and in the puppy (Bouchard et al., 1992). In the piglet, the comparison of bovine with porcine serum showed that absorption of Ig was better with porcine serum (Drew and Owen, 1988). In the lamb, serum was effective but whole blood tended to block intestinal absorption of Ig (Al-Jawad and Lees, 1985). Is this problem related to interference between Ig absorption and high levels of red blood cells in the blood? It should be remembered that the intestine is open not only to macromolecules but also to cells. This hypothesis should be studied, however it should not be forgotten that direct competition cannot occur since cells are absorbed by a intracellular route (Tuboly et al., 1988).

\section{Future developments}

Based on the studies performed and the literature reviews published, it is possible to conclude that the future of this subject lies in the consideration of colostrum as an industrial raw material. It is of course necessary to remind farmers of the most important things to do following the birth of an animal. However, the greatest improvement will be the development and the commercialisation of products derived form colostrum for the numerous cases where supply is more problematic than the system which is used to distribute colostrum.

The collection of colostrum, the extraction of a product which would be effectively absorbed in the intestine is something which is possible and has started to be used and has a future. However, it remains expensive since the quantities produced by each farmer remain very small compared to milk collection and treatment. In order to encourage the farmer to deliver, the price paid per litre needs to be high, so that at the end of the calving period the farmer notices that the extra work involved was worth the effort. The problem of the size of the production system is also seen at the industrial level. Its fixed charges are high. The product is still not well known and marketing will induce an increase in the selling price. Bearing this in mind the posology which can be used without being too expensive is greatly reduced. It is so reduced that it is not possible to detect an increase in circulating Ig. This type of approach is either intellectually dishonest or is hidden behind a pretended ignorance which will disqualify the seller. 
A dramatic decrease in the production costs by increasing the size of the operation or drastically changing the technology will not occur in the foreseeable future. In order to take into account the present day situation, it remains necessary to continue to prescribe very small quantities of colostrum. This system can work if the raw material is not just a collection of different colostrums but a hyper-immune colostrum produced by vaccination of the donor animals. The extra costs involved in this situation will be low when compared to the improvement in the Ig activity of the product. No extra charge will be incurred since all the rest of the technology and commercial processes will be the same.

At the present time the amount of information available for this type of system has begun to increase dramatically. The work has mainly looked at the intestinal pathologies which represent the main risk of young ungulates. Therefore, colostrums produced against viral antigens: rotavirus (Castrucci et al., 1984), coronavirus (Combs et al., 1993), bacterial antigens : Escherichia coli K99 (Combs et al., 1993) or parasitic antigens: Cryptosporidium parvum (Harp et al., 1989; Naciri et al., 1994) have been developed. The above pathological agents often provoke diarrhoea which can be severe, but one should not forget vectors for other pathogens like bovine rhinotracheitis caused by the bovine herpes virus (BHV-1) (Mechor et al., 1987). The treatments have often been successfull, but not always (Harp et al., 1989) due to too severe protocols. What is encouraging is that the efficiency against intestinal pathologies persisted even after closure. Treatment with hyper-immune bovine colostrum was not limited to the calf and was shown to be effective in the lamb (Naciri et al., 1984a,b) and the chicken infected with coccidiosis (Fayer and Jenkins, 1992). It should be noted that even the colostrum from a non-vaccinated dam can be effective against cryptosporidiosis in the calf (Robert et al., 1991) or the kid (Naciri et al., 1984a,b) but depends on random spontaneous immunisation of the dam.

At the same time research scientists had the idea that bovine colostrum could, for man, provide specific Ig in greater quantities and more easily available than horse serum which was used traditionally as a source of injectable Ig. Bovine Ig can only be used orally in the treatment of disease, and this type of treatment is therefore limited to intestinal diseases, which still represents a large field of action particularly for AIDS sufferers and the terminally ill. These studies are full of promise and position bovine colostrum as a future product of the pharmaceutical industry. Financial gains are higher when compared to the animal production sector, which is affected by low prices imposed by supermarket chains. This means that new products which are sold at prices which are relatively high have difficulty in finding a niche in the farm. This is true for colostrum products. Before being used in the farm sector they may need to find a place in human medicine.

A complete list of references concerning this subject is available from J.F. Grongnet. 


\section{REFERENCES}

Al-Jawad A.B., Lees J.L., 1985. Effects of ewe's colostrum and various substitutes on the serum immunoglobulin concentration, gut closure process and growth rate of lambs. Anim. Prod. 40, 123-127

Balbierz H., Nikolajczuk M., Sawicki T., 976. Observations on absorption of immunolactoglobulins in calves. Arch. Immunol. Ther. Exp. 24, 55-62

Balfour W. E., Comline R. S., 1962. Acceleration of the absorption of unchanged globulin in the new-born calf by factors in colostrum. J. Physiol. 160, 234-257

Beer A.E., Billinghan R.E., Read J., 1974. The immunologic significance of the mammary gland. J. Invest. Dermatol. 63, 65-74

Bernadina W.E., Franken P., 1983. Feeding bovine colostrum to lambs. Vet. Rec. 9, 47-48

Berthon P., Salmon H., 1993. Facteurs immunitaires des sécrétions mammaires. In: J. Martinet, L.-M. Houdebine (Editors). Biologie de la lactation, INRA-INSERM, Paris, pp. 389-414

Bertotto A., Gerli R., Castellucci G., Scalise F., Vaccaro R., 1991. Human milk lymphocytes bearing the gamma/delta T-cell receptor are mostly deltaTSC1-positive cells. Immunology 74 , 360-361

Bertotto A., Gerli R., Fabietti G., Crupi S., Arcangeli C., Scalise F., Vaccaro R., 1990. Human breast milk $\mathrm{T}$ lymphocytes display the phenotype and functional characteristics of memory $\mathrm{T}$ cells. Eur. J. Immunol. 20, 1877-1880

Besser T.E., Gay C.C., Pritchett L., 1991. Comparison of three methods of feeding colostrum to dairy calves. J. Amer. Vet. Med. Assoc. 198, 419-422

Besser T.E., Osborn D., 1993. Effect of bovine serum albumin on passive transfer of immunoglobulin G1 to newborn calves. Vet. Immunol. Immunopathol. 37, 321-327

Bielecka M., 1987. Investigations on the calf mortality. Part V. Influence or the genotype of calves and the way of giving colostrum on the lgG level in serum (in Polish). Rocz. Nauk rol., Ser. B, Zoot. 103, 87-95

Blecha F., Kelley K.W., 1981. Cold stress reduces the acquisition of colostral immunoglobulins in piglets. J. Anim. Sci. 52, 594-600

Bouchard G., Plata-Madrid H., Youngquist R.S., Buening G.M., Ganjam V.K., Krause G.F., Allen G., Paine A.L., 1992. Absorption of an alternate source of immunoglobulin in pups. Amer. J. Vet. Res. 53, 230-233

Bourne F.J., Curtis J., 1973. The transfer of immunoglobulins $\operatorname{lgG}$, IgA and IgM from serum to colostrum and milk in the sow. Immunology 24, 157-162

Brandon M.R., Lascelles A.K., 1971. Relative efficiency of absorption of $\operatorname{IgG} \mathrm{IgG}_{2}, \operatorname{lgGA}$ and $\operatorname{IgM}$ in the newborn calf. Aust. J. Exp. Biol. Med. Sci. 49, 629-633.

Brandtzaeg P., Krajci P., 1995. The enterocyte and immunoglobulin transport In: S. Auricchio, A. Ferguson, R. Troncone (Editors). Mucosal immunity and the gut epithelium : interactions in health and disease. Dyn. Nutr. Res. Vol. 4, Karger, Bâle, pp. 1-17

Brock J.H., Pineiro A., Lampreave F., 1978. The effect of trypsin and chymotrypsin on the antibacterial activity of complement, antibodies, and lactoferrin and transferrin in bovine colostrum. Ann. Rech. Vét. 9, 287-294

Burrin D.G., Davis T.A., Ebner S., Schoknecht P.A., Fiorotto M.L., Reeds P.J., McAvoy S., 1995. Nutrient-independent and nutrient-dependent factors stimulate protein synthesis in colostrumfed newborn pigs. Pediat. Res. 37, 593-599

Burrin D.G., Dudley M.A., Reeds P.J., Shulman R.J., Perkinson S., Rosenberger J., 1994. Feeding colostrum rapidly alters enzymatic activity and the relative isoform abundance of jejunal lactase in neonatal pigs. J. Nutr. 124, 2350-2357 
Burton J.L., Kennedy B.W., Burnside E.B., Wilkie B.N., Burton J.H., 1989. Variation in serum concentrations of immunoglobulins $\mathrm{G}, \mathrm{A}$ and $\mathrm{M}$ in Canadian Holstein-Friesian calves. J. Dairy Sci. 72, 135-149

Bush L.J., Contreras R., Staley T.E., Adams A.G., 1982. The effect of pasteurization of colostrum on absorption of immune globulins by calves. Anim. Res. Sci. 112, 246-249

Bush L.J., Staley T.E., 1980. Absorption of colostral immunoglobulins in newborn calves. J. Dairy Sci. 63, 672-680

Cabello G., Levieux D., 1978. The effect of thyroxine and climatic factors on colostral gammaglobulins absorption in newborn calves. Ann. Rech. Vét. 9, 309-318

Cabello G., Levieux D., 1981 a. Absorption and half life of bovine, caprine and ovine IgGl in the newborn lamb. Effect of experimental prematurity and endocrine factors. Ann. Rech. Vét. 12, $421-429$

Cabello G., Levieux D., 1981b. Absorption of colostral IgG by the newborn lamb: influence of the length of gestation, birthweight and thyroid function. Res. Vet. Sci. 31, 190-194

Cabello G., Levieux D., Girardeau J.P., Lefaivre J., 1983. Intestinal K99 Escherichia coli and absorption of colostral $\lg \mathrm{Gl}$ in the newborn lamb: effects of foetal infusion of thyroid hormones. Res. Vet. Sci. 35, 242-244

Cabello G., Levieux D., Lefaivre J., 1980. The effect of intra-amniotic injections of thyroxine on the absorption of colostral igGl by the newborn kid. Brit. Vet. J. 136, 193-194

Cabello G., Wrutniak C., 1986. Plasma free and total iodothyronine levels in the newborn lamb. Physiological considerations. Reprod. Nutr. Dévelop. 26, 1281-1288

Carlsson L.C.T., Westrom B.R., Karlsson B.W., 1980. Intestinal absorption of proteins by the neonatal piglet fed on sow's colostrum with either natural or experimentally eliminated trypsin-inhibiting activity. Biol. Nconate 38, 309-320

Castrucci G., Friegeri F., Ferrari M., Chili V., Caleffi F., Aldrovandi V., Nigrelli A., 1984. The efficacy of colostrum from cows vaccinated with rotavirus in protecting calves to experimentally induced rotavirus infection. Comp. Immun. Microbiol. Infect. Dis. 7, 11-18

Chan W.S., Daniels V.G., Thomas A.L., 1973. Premature cessation of macromolecule uptake by the young rat intestine following thyroxin administration. J. Physiol. 231, 112-125

Charles D., Larsen B., 1984. How colostrum and milk protect the newborn. Contemp. Ob. Gyn. 24, 143-166

Combs D.K., Bringe A.N., Lopez. J.W., Crabb J.H., Ruch F.E., 1993. Protection of neonatal caives against K99-E. coli and coronavirus using a colostrum-derived immunoglobulin preparation. Agri-Practice 14 (5), 13-16

Constant S.V., Leblanc M.M., Klapstein E.F., Beebe D.E., Leneau H.M., Nunier C.J., 1994. Serum immunoglobulin $\mathrm{G}$ concentration in goat kids fed colostrum or a colostrum substitute. J. Amer. Vet. Med. Assoc. 205, 1759-1762

Cruywagen C.W., 1990. Effect of curd forming on absorption of immunoglobulin $\mathrm{G}$ in newborn calves. J. Dairy Sci. 73, 3287-3290

Dardillat J., Trillat G., Larvor P., 1978. Colostrum immunoglobulin concentrations in cows: relationships with their calf mortality and with the colostrum quality of their femalc off spring. Ann. Rech. Vét. 9, 375-384

Delouis, C., 1978. Physiology of colostrum production. Ann. Rech. Vét. 9, 193-203

Derenbach J., Langholz H.-J., Schmidt F.-W., Kim J.W., 1983. Colostrum intake in newborn calves. Z. Tier Zücht. Züchtgsbiol. 100, 175-186

Dixon F.J., Weigle W.O., Vazquez J.J., 1961. Metabolism and mammary secretion of serum proteins in the cow. Lab. Invest, 10,216-236 
Dobbelaar P.. Noordhuizen J.P.T.M., Van Keulen K.A.S.. 1987. An epidemiologiacl study of gammaglobulin levels in newborn calves. Prev. Vet. Med. 5, 51-62

Dos Santos G.T., Grongnet J.F., Nunes Do Prado I., 1994a. Efeito da presenća maternal sobre a absorćao intestinal de immunoglobulinas Gl por cordeiros recem-nascidos. Rev. Soc. Brasil. Zoot. 23, 119-125

Dos Santos G.T., Grongnet J.F., Nunes Do Prado I., 1994 b. Influencia da hipoxia sobre absorćao intestinal de immunoglobulinas G1 do colostro pelos bezerros recem-nascidos. Arq. Biol. Tecnol. $37,181-189$

Drew M.D., Owen B.D., 1988. The provision of passive immunity to colostrum-deprived piglets by bovine or porcine serum immunoglobulins. Can. J. Anim. Sci. 68, 1277-1284

El-Nageh M.M., 1967a. Siège de l'absorption intestinale des gammaglobulines du colostrum chez le veau nouveau-né. $\Lambda \mathrm{nn}$. Méd. Vét. 6, 380-383

El-Nageh M.M., 1967b. Voies d'absorption des gammaglobulines du colostrum au niveau de l'intestin grźle du veau nouveau-né. Ann. Med. Vét. 6, 384-393

Encheva Y., Planski B., Vassilev V., Poshtakov E., 1987. Utilization of colostrum immunoglobulins in calves. Vet. Sci. 24 (3), 14-20

Evans P.A., Newby T.J., Stokes C.R., Bourne F.J., 1982. A study of cells in the mammary secretions of sows. Vet. Immunol. Immunopathol. 3,515-527

Falion R.J., Harte F.J., 1987. A survey of factors affecting calf blood serum immunoglobulin level. Irish J. Agric. Res. 26, 1-7

Fallon R.J., Harte F.J., Keane M.G., 1989. Methods of artificially feeding colostrum to the newborn calf. Irish J. Agric. Res. 28, 57-63

Fayer R., Jenkins M.C., 1992. Colostrum from cows immunized with Eimeria acervulina antigens reduces parasite development in vivo and in vitro. Poultry Sci. 71, 1637-1645

Fetcher A., Gay C.G., Mc Guire T.C., Barbee D.D., Parish S.M., 1983. Regional distribution and variation of gammaglobulin absorption from the small intestine of the neonatal calf. Amer. $\mathrm{J}$. Vet. Res. 44, 2149-2154

Foley W.A., Hunter A.G., Otterby D.E., 1978. Absorption of colostral proteins by newborn calves fed unfermented, fermented of buffered colostrum. J. Dairy Sci., 61, 1450-1456

Frenyo V.L., 1987. Studies on the absorption of homologous and heterologous $\operatorname{IgC}$ in artificially reared newborn pigs. Vet. Res. Commun. 11, 23-30

Grongnet J.F., Dos Santos G.T., Piot M., Toullec R., 1996. Influence of bovine colostrum thermisation on immunoglobulin intestinal transfer in newborn lambs. J. Anim. Feed Sci. 4, 333-339

Grongnet J.F., Grongnet-Pinchon E., Levieux D., Piot M., Lareynie J., 1986. Newborn calf intestinal absorption of immunoglobulins extracted from colostrum. Reprod. Nutr. Dévelop. 26, 731-743

Guidry A.J., Butler J.E., Pearson R.E., Weinland B.T., 1980. Immunoglobulin A, immunoglobulin $\mathrm{G} 1$, immunoglobulin $\mathrm{G} 2$, immunoglobulin $\mathrm{M}$ and bovine serum albumine in serum and mammary secretion throughout lactation. Vet. Immunol. Immunopathol. 1, 329-342

Halliday R., 1978. Variation in immunoglobulin transfer from ewes to lambs. Ann. Rech. Vét. 9, 367-374

Halliday R., $1979 \mathrm{a}$. The effects of steroids hormones on the absorption of antibody by the young rat. J. Endocrinol. 18, 56-66

Halliday R., 1979b. La variabilité génétique du transfert d'immunoglobulines de la mère é ses produits. Ses effets sur la croissance et la viabilité. Bull. Tech. Dep. Génét. Anim. 29/30, 275-283

Hammer D.K., Mossman H., 1978. The importance of membrane receptors in the transfer of immunoglobulins from plasma to the colostrum. Ann. Rech. Vét. 9, 229-234

Harada E., Syuto B., 1993. Secretin induces precocious cessation of intestinal macromolecular transmission and maltase development in the suckling rat. Biol. Neonate 63, 52-60 
Harp J.A., Woodmansee D.B., Moon H.W., 1989. Effects of colostral antibody on susceptibility of calves to Cryptosporidium parvum infection. Amer. J. Vet. Res. 50, 2117-2119

Honkanen-Buzalski T., Sandholm M., 1981. Trypsin-inhibitors in mastitic milk and colostrum: correlation between trypsin-inhibitor capacity, bovine serum albumin and somatic cell contents. J. Dairy Res. 48, 213-223

Huang S.-C., Hu Z., Hasler-Rapacz J., Rapacz J., 1992. Preferential mammary storage and secretion of immunoglobulin gamma (IgG) subclasses in swine. J. Reprod. Immunol. 21, 15-28

Israel E.J., Simister N., Freiberg E., Caplan A., Walker W.A., 1993. Immunoglobulin G binding sites on the human foetal intestine : a possible mechanism for the passive transfer of immunity from mother to infant. Immunology 79, 77-81

Iivanainen A., Hottta E., Stahls A., Andersson L.C., 1992. Colostral growth factors. Possible role in bovine udderepithelial cell regeneration. Acta. Vet. Scand. 33, 197-203

James R.E., Polan C.E., 1978. Effect of orally administered duodenal fluid on serum proteins in neonatal calves. J. Dairy Sci. 61, 1444-1449

James R.E., Polan C.E., Cummins K.A., 1981. Influence of administered indigenous microorganisms on uptake of $125 \mathrm{I}$-gamma-globulin in vivo by intestinal segments of neonatal calves. J. Dairy Sci. 64, 52-61

Jensen P.T., Pedersen K.B., 1979. Studies on immunoglobulins and trypsin inhibitor in colostrum and milk from sows and in serum of their piglets. Acta. Vet. Scand. 26, 60-72

Jetteur P., Robert B., Maquet G., Gregoire R., Pivont P., Lacroix J.-P., Antoine H., 1987. Effets du rayonnement gamma sur la valeur immunitaire et la contamination microbienne et virale du colostrum bovin. Ann. Med. Vét. 131, 543-552

Jochims K., Kaup F.-J., Drommer W., 1994. Immunoelectron microscopical demonstration of the absorption of colostral IgG by small intestinal enterocytes in newborn rats. Res. Vet. Sci. 57, 146-151

Johnston N.E., Stewart J.A., 1986. The effect of glucocorticod's and prematurity on absorption of colostral immunoglobulin in the calf. Aust. Vet. Rec. 63, 191-192

Joly G., 1981. Contribution á l'influence de la race, de la prématurité et de la présence matemelle sur l'acquisition de l'immunité passive par le veau. Mémoire de D.E.A., Unjversité de Rennes I, pp. 50

Jones L.R., Taylor A.W., Hines H.C., 1987. Characteristics of frozen colostrum thawed in a microwave oven. J. Dairy Sci. 70, 1941-1945

Kaeckenbeeck A., El-Nageh M., Schoenaers F., 1967. Effets d'une première administration de protéines sur la résorption intestinale ultérieure des globulines, chez le veau nouveau-né. Ann. Med. Vét. 111, 391-399

Karle G., Szucs E., Acs I., Szentpeteri J., Frenyo V.L., Csiba A., 1987. Effect of feeding colostrum on performance of dairy calves. World Rev. Anim. Prod. 23, 55-58

Kelley K.W., Blecha F., Regnier J.A., 1982. Cold exposure and absorption of colostral immunoglobulins by neonatal pigs. J. Anim. Sci. 55, 363-368

Kelly D., King T.P., McFadyen M., Coutts A.G.P., 1993. Effect of preclosure colostrum intake on the development of the intestinal epithelium of artificially reared piglets. Biol. Neonate 64 , 235-244

Kiriyama H., 1992. Enzyme linked immunosorbent assay of colostral lgG transported into lymph and plasma in neonatal pigs. Amer. J. Physiol. 263, R976

Klein R.M., McKenzie J.C., 1980. Pattern of crypt cell proliferation in the pre- and post-closure ileum of the neonatal rat : effects of sympathectomy. Cell Tissue Res. 206, 387-394

Klobasa F., Greimann H., Kallweit E., 1994. Investigation on the delay interval between birth of lambs and their first ingestion of bovine colostrum. Berl. Mün. Tierärztl. Wochenschr. 107, 334-339 
Kohn C.W., Knight D., Hueston W., Jacobs R., Reed S.M., 1989. Colostral and serum IgG, IgA, and IgM concentrations in standardbred mares and their foals at parturition. J. Amer. Vet. Med. Assoc. 195, 64-68

Larson B.L., Heary H.L., Devery J.E., 1980. Immunoglobulin production and transport by the mammary gland. J. Dairy Sci. 63, 665-67!

Lavoie J.-P., Spensley M.S., Smith B.P., Bowling A.T., Morse S., 1989a. Complement activity and selected hematologic variables in newborn foals fed bovine colostrum. Amer. J. Vet. Res. 50, $1532-1536$

Lavoie J.-P., Spensley M.S., Smith B.P., Mihalyi J., 1989b. Absorption of bovine colostral immunoglobulins $G$ and $M$ in newborn foals. Amer. J. Vet. Res. 50, 1598-1603

Le Dividich J., Noblet J., 1981. Colostrum intake and thermoregulation in the neonatal pig in relation to environmental temperature. Biol. Neonate 40, 167-174

Le Huérou-Luron 1., Guilloteau P., Wicker-Planquart C., Chayvialle J.-A., Burton J., Mouats A., Toullec R., Puigserver A., 1992. Gastric and pancreatic enzyme activities and their relationship with some gut regulatory peptides during postnatal development and weaning in calves. J. Nutr. $122,1434-1445$

Le Jan C., 1992. Caractérisation des cellules du colostrum et du lait chez la truie. Journées Rech. Porcine 24, 309-314

Lecce J.G., Morgan D.O., 1962. Effect of dietary regimen on cessation of intestinal absorption of large molecules in the neonatal pig and lamb. J. Nutr. 78, 263-267

Lecce J.G., Morgan D.O., Matrone G., 1964. Effects of feeding colostral and milk components on the cessation of intestinal absorption of large molecules (closure) in neonatal pigs. J. Nutr. 84, 43.48

Lee C.S., Outteridge P.M., 1981. Leucocytes of sheep colostrum, milk and involution secretion with particular reference to ultrastructure and lymphocyte sub-populations. J. Dairy Res. 42, 225237

Levieux D., 1984. Transmission de l'immunité passive colostrale: le point des connaissances. In R. Jarrige (Editor). Physiologie et pathologie périnatales chez les animaux de ferme. INRA, Paris, pp. 346-369

Li-Chan E., Kummer A., Losso J.N., Kitts D.D., Nakai S., 1995. Stability of bovine immunoglobulins to thermal treatment and processing. Food Res. Int. 28, 9-16

Malinowska K.W., Hardy R.N., Nathanielsz P.W., 1972. Neonatal adrenocortical function and its possible relation to the uptake of macromolecules by the small intestine of the guinea-pig and rabbit. J. Endocrinol. 55, 397-404

Matte J.J., Girard C.L., Seoane J.R., Brisson G.J., 1982. Absorption of colostral immunoglobulin G in the newborn dairy calf. J. Dairy Sci. 65, 1765-1770

McCoy G.C., Reneau J.K., Hunter A.G., Williams J.B., 1970. Effects of diet and time on blood serum protein in newborn calf. J. Dairy Sci. 53, 358-362

Mechor G.D., Rousseaux C.G., Radostits O.M., Babiuk L.A., Petrie L., 1987. Protection of newborn calves against fatal multisystemic infectious bovine rhinotracheitis by feeding colostrum from vaccinated cows. Can. J. Vet. Res. 51, 452-459

Mehrazar K., Gilman-Sachs A., Kim Y.B., 1993. Intestinal absorption of immunologically intact macromolecules in germiree colostrum-deprived piglets maintained on total parenteral nutrition. J. Parent. Ent. Nutr. 17, 8-15

Mehta P.D., Mehta S.P., Isaacs C.E., 1989. Distribution of IgG subclasses in human colostrum and milk. Immunol. Lett. 22, 235-238

Merilainen V., Mayra A., Korhonen H., Antila M., Uusi-Rauva A., 1979. Cells in bovine colostrum and properties of the lymphocyte population. Meijeritiet. Aikak. 37, 45-58 
Michanek P., Ventorp M., 1989. Intestinal transmission of macromolecules in newborn dairy calves of different ages at first feeding. Res. Vet. Sci. 46, 375-379

Michanek P., Ventrop M., 1993. Passive immunization of newborn dairy calves on three farms with different housing systems. Swedish J. Agric. Res. 23, 37-43

Milon A., Aumaitre A., Le Dividich J., Franz J., Metzger J.J., 1983. Influence of birth prematurity on colostrum composition and subsequent immunity of piglets. Ann. Rech. Vét. 14, 533-540

Murata H., Namioka S., 1977. The duration of colostral immunoglobulin uptake by the epithelium of the small intestine of neonatal piglets. J. Comp. Pathol. 87, 431-439

Naciri M., Macassola R., Reperant J.-M., Canivez O., Quinque B., Yvore P., 1994. Treatment of experimental ovine cryptosporidiosis with ovine or bovine hyperimmune colostrum. Vet. Parasitol. 53, 173-190

Naciri M., Yvore P., Levieux D., 1984a. Cryptopsoridiose expérimentale du chevreau. Importance de la prise du colostrum. Les colloques de l'INSERM 121, 269-276

Naciri M., Yvore P., Levieux D., 1984b. Cryptosporidiose expérimentale du chevreau. Influence de la prise de prise de colostrum. Essais de traitements in INRA: Les maladies de la chèvre, Paris, pp. $465-471$

Newbold F.H.S., 1970. Enhancement of phagocytosis in bovine milk leucocytes in vitro. Can. J. Comp. Med. 34, 261-264

Newby T.J., Bourne F.J., 1977. The nature of the local immune system of the bovine mammary gland. J. Immunol. 118, 461-465

Nousiainen J. Korhonen H., Syväoja E.-L., Savolainen S., Saloniemi H., Jalonen H., 1994. The effect of colostral immuoglobulin supplement on the passive immunity, growth and health of neonatal calves. Agric. Sci. Finland 3, 421-428

Olson D.P., Bull R.C., Woodard L.F., Kelley K.W., 1981. Effects of maternal nutritional restriction and cold stress on young calves: absorption of colostral immunoglobulins. Amer. J. Vet. Res. 42, 876-880

Olson D.P., Papasian C.J., Ritter R.C., 1980. The effect of cold stress on neonatal calves. 2. Absorption of colostral immunoglobulins. Can. J. Comp. Med. 44, 19-23

Patureau-Mirand P., Mosoni L., Levieux D., Attaix D., Bayle G., Bonnet Y., 1990. Effect of colostrum feeding on protein metabolism in the small intestine of newborn lambs. Biol. Neonate 57 , 30-36

Payne L.C., Marsh C.L., 1962a. Gammaglobulin absorption in the baby pig. The non-selectiveabsorption of heterologous globulins and factors influencing absorption time. J. Nutr. 76, 151-158

Payne L.C., Marsh C.L., 1962b. Absorption of gammaglobulin by the small intestine. Fed. Proc. 21, 909-912

Petschow B.W., Talbott R.D., 1994. Reduction in virus-neutralizing activity of a bovine colostrum immunoglobulin concentrate by gastric acid and digestive enzymes. J. Pediat. Gastroenterol. Nutr. 19, 228-235

Pineiro A., Ortega F., Uriel J., 1975. Trypsin inhibitor from cow colostrum. Isolation, electrophoretic characterization and immunologic properties. Biochim. Biophys. Acta 379, 201-206

Prosser C.G., Eichler S.J., Farr V.C., Davis S.R., 1992. Effect of colostrum intake on alpha-lactalbumin concentrations in serum of calves. Res. Vet. Sci. 53, 219-222

Quigley J.D., Martin K.R., Bemis D.A., Potgieter C.R., Reinemeyer C.R., Rohrbach B.W., Dowlen H.H., Lamar K.C., 1995a. Effects of housing and colostrum feeding on serum immunoglobulins, growth and fecal scores of Jersey calves. J. Dairy Sci. 78, 893-901

Quigley J.D., Martin K.R., Dowlen H.H., 1995b. Concentrations of trypsin inhibitor and immunoglobulins in colostrum of Jersey cows. J. Dairy Sci. 78, 1573-1577 
Quigley J.D., Martin K.R., Dowlen H.H., Lamar K.C., 1995c. Addition of soybean trypsin inhibitor to bovine colostrum : effects on serum immunoglobulin concentrations in Jersey calves. J. Dairy Sci. 78, 886-892

Rapacz. J., Hasler-Rapacz J., 1982. Immunogenetics studies of polymorphism, potsnatal passive acquisition and development of immunoglobulin gamma ( $\mathrm{IgG})$ in swine. Proceedings of the 2nd World Congress Gen. Applied Livestock Production 6, 365-374

Reinhart G.A., Simmen F.A., Mahan D.C., White M.E., Roehrig K.L., 1992. intestinal development and fatty acid binding protein activity of newborn pigs fed colostrum or milk. Biol. Neonate 62 , 155-163

Robert B., Collard A., Coppe P., Ginter A., Antoine H., 1991. Epidémiologie de la cryptosporidiose bovine dans une ferme belge ; essai de prévention á l'aide de colostrum. Ann. Med. Vét. 135, 441-446

Salmon H., Delouis C., 1982. Cinćtique de sous-populations lymphocytaires et des plasmocytes dans la mamelle de truie primipare en relation avec la gestation et la lactation. Ann. Rech. Vét. $13,41-49$

Sasaki M., Larson B.L., Nelson D.R., 1977. Kinctic analysis of the binding of immunoglobulins IgG1 and IgG2 to bovine mammary cells. Biochim. Bioph. Acta 497, 160-170

Schlesinger J.J., Covelli H.D., 1977. Evidence for the transmission of lymphocytes responses to tuberculin by breast-feeding. Lancet $529-532$

Schollenberger A., Degorski A., Frymus T., Schollenberger A., 1986. Cells of sow mammary secretions. I- Morphology and differential counts during lactation. J. Vet. Med. 33, 31-38

Schreuder B.E.C., 1993. Thrombocytopenia in lambs fed with bovine colostrum. Vet. Quart. 15, $37-39$

Selman I.E., McEwan A.D., Fisher E.W., 1971a. Studies on dairy calves allowed to suckle their dams at fixed times post-partum. Res. Vet. Sci. 12, 1-6

Selman I.E., McEwan A.D., FischerE.W., 1971b. Absorption of immune lactoglobulin by newborn dairy calves : attempts to procedure consistent immunoglobulin absorptions in newborn calves using standardised methods of colostrum feeding and management. Res. Vet. Sci. 12, 205-210

Simister N.E., Mostov K.E., 1989. An Fe receptor structurally related to MHC class I antigens. Nature 337, 184-187

Ślebodziński A.B., Lipczak W., Brzezińska-Ślebodzińska E., 1995. Peroral administration of triiodothyronine (T3) affects absorption of immunolactoglobulins in calves. Reprod. Nutr. Dévelop. 35, 387-393

Smith T., Little R., 1922. Cow serum as a substitute for colostrum in newborn calves. J. Exp. Med. 36, 453-468

Smith M.W., Pierce A.E., 1967. Effect of amino acids on the transport of bovine immuno-lactoglobulin accross newborn pig intestine. Nature 213,1150-1151

Stott G.H., 1980. Immunoglobulin absorption in calf neonates with special consideration of stress. J. Dairy Sci. 63, 681-688

Stott G.H., Reinhard E.J., 1978. Adrenal function and passive immunity in the dystocial calf. J. Dairy Sci. 61, 1457-1461

Todd A.G., Whyte P.B.D., 1995. The effect of delays in fecding colostrum and the relationship between immunoglobulin concentration in the serum of neonatal calves and their rates of growth. Aust. Vet. J. 72, 415-417

Tuboly S., Bernath S., Glavits R., Medveczky I., 1988. Intestinal absorption of colostral lymphoid cells in newborn piglets. Vet. Immunol. Immunopathol. 20, 75-85

Tyler H., Ramsey H., 1991. Hypoxia in neonatal calves: effect on intestinal transport of immunoglobulins. J. Dairy Sci. 74, 1953-1956 
Tyler H., Ramsey H., 1993. Effect of insulin-induced hypoglycemia on cessation of macromolecular transport in the neonatal calf. J. Dairy Sci. 76, 2736-2741

Ventorp M,, Michanek P., 1992. The importance of udder and teat conformation for teat sceking by the newborn calf. J. Dairy Sci. 75, 262-268

Villette Y., Levieux D., 1981. Etude de l'influence de l'âge de la mčre sur la transmission de l'immunité passive colostrale chez l'agneau. Ann. Rech. Vét. 12, 227-231

Walker W.A., Cornell R., Davenport L.M.. Isselbacher K.J., 1972. Macromolecular absorption: mechanism of horseradish peroxydase uptake and transport in adult and neonatal rat intestine. J. Cell. Biol. 54, 195-205

Watanabe T., Ohta C., Shirahata T., Goto H., Tsunoda N., Tagami M., Akita H., 1993. Preventive administration of bovine colostral immunoglobulins for foal diarrhea with rotavirus. $J$. Vet. Med. Sci. 55, 1039-1040

Werhan E., Klobasa F., Butler J.E., 1981. Investigation of some factors which influence the absorption of IgG by the neonatal piglet. Vet. Immunol. Immunopathol. 2, 35-5I

Williams P.P.,1993. Immunomodulating effects of intestinal absorbed maternal colostrum leucocytes by neonatal piglets. Can. J. Vet. Res. 57, 1-8

Winter A.C., Clarkson M.J., 1985, Farm investigations of anemia in lambs caused by feeding cow colostrum. Vet. Rec. 131, 213-216

Zaremba W., Guterbock W.M., Holmberg C.A., 1993. Efficacy of dried colostrum powder in the prevention of disease in neonatal holstein claves. J. Dairy Sci. 76, 831 